\title{
СУДЬБА ТОЛКОВОЙ ПСАЛТЫРИ МАКСИМА ГРЕКА (к истории развития кирилло-мефодиевских традиций в Московии)
}

\begin{abstract}
Шулежкова С. Г. Доля Толкового Псалтиря Максима Грека (до історії розвитку кирило-мефодіївських традицій у Московії)

Толковий Псалтир опинився на периферії філологічних досліджень. Гоніння, звинувачення Максима Грека в єресі першкоджали його публікації. Виданий у 1897 р., Псалтир відображає літературну мову 1-ї половини XVI ст. і новаторський підхід письменника до перекладу богослужбових книг, що виявився в нормуванні церковнослов'янської мови та поміркованої її русифікації. Пам'ятка надає широкі можливості задля всебічного вивчення літературної мови своєї епохи.

Ключові слова: Максим Грек, Толковий Псалтир, переклад, церковнослов'янська мова, нормалізація, русифікація.
\end{abstract}

Шулежкова С. Г. Судьба Толковой Псалтыри Максима Грека (к истории развития кирилло-мефодиевских традиций в Московии)

Толковая Псалтырь оказалась на периферии филологических исследований. Опала, обвинения Максима Грека в ереси препятствовали её публикации. Изданная в 1897 г., Псалтырь отражает литературный язык 1-й половины XVI в. и новаторский подход писателя к переводу богослужебных книг, проявившийся в нормировании церковнославянского языка и умеренной его русификации. Памятник предоставляет широкие возможности для всестороннего изучения литературного языка своей эпохи.

Ключевые слова: Максим Грек, Толковая Псалтырь, перевод, церковнославянский язык, нормализация, русификация.

Shulezhkova S. G. Destiny of the Explanatory Psalter by Maximus the Greek (to the history of the development of Sts Cyril and Methodius`s tradition in Moscow)

The Explanatory Psalter [Tolkovaia Psaltyri] written by Maximus The Greek [Maksim Grekh] found itself on the periphery of the philological research. Its author's falling into disgrace and being accused of heresy precluded the publication of the Explanatory Psalter. Published in 1897 the Explanatory Psalter shows the literary language of the $1^{\text {st }}$ half of the XVI ${ }^{\text {th }}$ century. It also manifests the author's innovative approach to the translation of the Holy books which included normalization and russification of the Church Slavonic language. The manuscript presents ample opportunity for the comprehensive and thorough study of the literary language of its time.

Key words: Maximus The Greek [Maksim Grekh], The Explanatory Psalter [Tolkovaia Psaltyri], translation, the Church Slavonic language, normalization, russification.

1200-летие со дня рождения святого равноапостольного Мефодия, одного из братьев-подвижников, подаривших славянам письменность, и 1000-летие со дня смерти князя Владимира, Крестителя Киевской Руси, 
совпали с другой знаменательной датой. 500 лет тому назад «великий и преславный князь всея Руси» Василий Иванович и митрополит Варлаам обратились к монахам Ватопедского монастыря с просьбой прислать в Москву переводчика богослужебных книг. Если бы не это прошение, мир никогда бы не узнал русского писателя, переводчика, богослова и публициста Максима Грека, одного из самых выдающихся последователей солунской двоицы, творивших на восточнославянских землях. Несмотря на то, что наследию Максима Грека посвящено множество работ исторического, текстологического, литературоведческого, богословского характера, учёные явно недостаточное внимание уделяли, пожалуй, самому выдающемуся его переводному творению - Толковой Псалтыри. Цель данного исследования - проследить историю создания и бытования Толковой Псалтыри, оценить её влияние на формирование переводческих традиций в России и наметить пути её лингвистического изучения.

У Толковой Псалтыри, сыгравшей решающую роль в биографии Максима Грека, была необычная судьба, как необычной, полной взлётов и падений, была судьба её переводчика. Именно «превожение» ('перевод') Толковой Псалтыри, который был задуман великим князем Василием, отцом Ивана Грозного, послужил толчком к превращению афонского инока в крупнейшую фигуру русской культуры XVI в.

Изданная в 1897 г., Псалтырь Толковая Максима Грека, переписанная «не с единого списка, но с различных добрых переводов» в 1592 г. по велению Вологодского и Великопермского архиепископа Ионы Думина [Послесловие 1592], неведомыми путями попала в Магнитогорск в начале 30-х годов прошлого века. И хранится она сейчас в фонде редких книг Магнитогорского государственного технического университета им. Г. И. Носова. Это огромный фолиант с обложками из деревянных досок, обтянутых кожей. И на корешке, и на лицевой стороне обложки можно прочесть короткое её название - «Святая Книга». Никто не знает ни бывших владельцев книги, ни обстоятельств её появления в вузовской библиотеке. Судя по сохранившимся обрывкам записей, хозяевами книги были священники, однако их имена старательно стёрты, а немногочисленные пометы представляют собою ссылки на страницы, посвящённые сущности церкви и её роли в жизни христиан. В Магнитку, вероятно, её привёз кто-то из ссыльных. Знакомство с этой книгой и послужило толчком к данному исследованию.

Ответы на целый ряд вопросов, связанных с возникновением Псалтыри Толковой, можно найти в предисловии Толковой Псалтыри, представляющем собою Послание Максима Грека основному заказчику, (с) С. Г. Шулежкова, 2015. 
царю Василию III [Послание 1522]. В первой четверти XVI столетия и царь Василий III, и митрополит Варлаам, и многие другие образованные люди Московии осознавали необходимость «унификации церковной службы», которую нельзя было осуществить «без точного перевода и исправления служебных книг» $[18$, с. 81$]$. Значительная же часть канонических христианских книг, собранных в государевой библиотеке, была написана на древнегреческом языке. К таковым относилась и Псалтырь Толковая, всерьёз заинтересовавшая Василия III, которому в наследство от матери, Софии Палеолог, досталось немало старинных книг. В своём послании к «благовернейшему и вышшему царю и богохранимому государю великому князю Василию Ивановичу всея Руси» [Послание 1522: л. à] Максим Грек говорит, что эти толкования псалмов «в книгохранильнице заключенные» и моли одной «в ядь предлежавшие», долгое время никакую пользу людям не приносили [Там же: л. â]. Своих переводчиков с греческого языка на Руси не было: после захвата турками в 1453 Константинополя культурные, политические и торговые связи с колыбелью православия сократились, дипломатические контакты поддерживались по преимуществу с западными соседями на латыни, а потому особой нужды в людях, владеющих греческим языком, не было.

Несмотря на то, что в Европе книгопечатание с середины XV в. активно осваивалось, русичи по-прежнему осторожно относились к изобретению И. Гуттенберга и довольствовались рукописными книгами. Переписывание книг было почётным, к тому же доходным занятием, и многочисленные писцы не были заинтересованы в книгопечатании. Поскольку далеко не все они получили хорошее образование, в религиозных книгах появлялось множество неточностей, ошибок, что нередко приводило к искажению самой сути текстов. Чтобы унифицировать богослужение, необходимо было сверить требники с первоисточниками. Отсутствие собственных «добрых» переводчиков с греческого вынудило царя и митрополита обратиться за помощью к монахам, чьи обители, как и все земли бывшей Византийской империи, оказались под властью турок.

К тому моменту, когда русское посольство прибыло на Афон, выходец из богатой аристократической семьи Михаил Триволис, получивший блестящее образование в университетах Европы, успел прослужить около года в итальянском монастыре, которым руководил в своё время неистовый Савонарола, разочаровался в католицизме и вёл подвижническую жизнь в православном Ватопедском монастыре. Именно здесь при пострижении он был назван Максимом в честь 
преподобного Максима Исповедника.

Оплот православия в покорённой турками Греции, Ватопедский мужской монастырь, с его аскетическим уставом, с монахами, славящимися своей учёностью, вполне соответствовал внутренним потребностям Михаила Триволиса. В 1515 г. это был зрелый учёный, богослов, который «намеревался всю жизнь посвятить монашескому подвигу и изучению святоотеческого наследия. В течение 10 лет Максим Грек пребывал на Афоне и продолжал заниматься своим образованием. Учёность Максим приобрёл колоссальную, и удивительным образом те духовные знания, которые он сумел стяжать, Промысел Божий определил направить на Русь, которой они были крайне необходимы в это тяжёлое время угасания православной учёности» $[8, \mathrm{http}]$.

Направляя в 1515 г. своих послов в Оттоманскую империю, в состав которой входили тогда греческие земли вместе со Святой Горой Афон, царь Василий «призывал от честныя обители Ватопеди Сав(в)у некоего», намереваясь именно Сав(в)е поручить перевод Толковой Псалтыри с греческого языка на церковнославянский, но тот отказал «царствующему всея Руси» из-за старости, и тогда выбор пал на монаха Максима [Послание 1522: л. â]. Вполне возможно, что главной причиной приглашения Сав(в)ы было то, что тот владел русским языком, а перепоручение столь важной миссии Максиму было знаком признания его широчайшей эрудиции.

Максим Грек прибыл в Москву 4 марта 1518 г., спустя три года после отправки Василием III послов на Афон [12, с. 61]. Будучи высокообразованным учёным, ватопедский инок, наверняка, серьёзно готовился к кратковременному, как ему казалось поначалу, визиту в чужую страну. Когда пишут о том, что Максим Грек русскому языку обучался лишь при жизни в России, упускают из внимания промежуток времени между решением ватопедской братии отправить Максима в Москву и реальным днём его приезда в российскую столицу. Известно, что вместе с Максимом Греком в Россию прибыли посланец константинопольского патриарха Феолипта митрополит Григорий Грек, патриарший дьякон Дионисий Грек, ватопедские монахи Неофит священноинок и Лаврентий Болгарин [12, с. 61]. Но особенно для нас важен тот факт, что в составе посольства был Сав(в)а игумен [Там же], посланец русского Пантелеймонова монастыря, расположенного на Афоне, то есть географически близко к месту нахождения обители Максима Грека. Представить себе русский монастырь без церковнославянских богослужебных книг вряд ли возможно. Доказательством того, что Максим Грек осваивал и русскую речь, и (С С. Г. Шулежкова, 2015. 
церковнославянский язык ещё до прибытия в Москву, служит та скорость, с которой он справился с переводом апостольских посланий, а затем с переводом Толковой Псалтыри в России. Н. Синицына в монографии «Максим Грек» не без основания предполагает: «.Возможно, ему всё же был знаком какой-то извод церковнославянского языка, если он совершал миссионерские поездки в Валахию, а возможно, и в другие Балканские страны. Кроме того, среди монахов, ехавших в Москву вместе с Максимом, был Лаврентий, болгарин из Ватопеда. Надо полагать, что он выполнял функции переводчика; во время долгого, двухлетнего пути в Москву он мог обучать языку своего спутника, а в ходе переводов, слушая русскую речь своих помощников, запоминая русские эквиваленты латинских слов, выражений, фраз, он сам усваивал этот язык» [11, http].

М. Сперанский считает, что видеть в переводе первых книг «славянорусский язык Максима Грека мы не можем» [15, с. 175]. Однако существуют объективные доказательства того, что посланец из Ватопедского монастыря не только руководил коллективом сотрудников, готовивших церковнославянский вариант Толковой Псалтыри, но и сам принимал активное участие в переводческой работе, неустанно совершенствуя свои знания и в русском разговорном языке, и в русском изводе церковнославянского книжного языка.

Отличительная особенность переводческой деятельности Максима Грека в первые годы его пребывания в России - тесное сотрудничество с русскими каллиграфами, толмачами, писцами и другими помощниками. В своём Послании царю Василию III, которое сопровождало перевод Толковой псалтыри, Максим Грек, говоря о том, что он «многотрудное дело сие сподобился вконец довести паче великаго чаяния», постоянно подчёркивает участие в переводе Псалтыри и русичей. «На свет изведши» Давыдовы псалмы, переведя их с греческого языка на русский, он, «не себя похваляя», а от имени своих сподвижников прося царя принять «общее и духовное брашно», «боговдохновенное» и «богодарованное дело», сопровождает своё подношение словами: «Труд от нас есть во славу Божию» [Послание 1522: л.•с̧•об. - л.•ѐ॰]. В этом же Послании Максим Грек ходатайствует о вознаграждении «сотрудившихся», называя их: «Власа и Митю - толмачей; и Михаля Медоварцова, и Силвана инока, и брата нашего - писарей; и малейших служебников царствия твоего и по знати да изволиши и трудов их помнити» [Там же: л.•ѐ- - л.•ѐ• об.].

Толковая Псалтырь - вторая переводная работа, выполненная Максимом Греком и его сотрудниками в Москве. До марта 1519 или 1520 г. они завершили работу над Толковым Апостолом [7, с. 100]. Митя и Влас из 
Послания к Василию III - это Дмитрий Герасимов и Власий Игнатов, известные посольские толмачи, а также крупные дипломаты своего времени. Максим переводил греческий текст Псалтыри на латынь, а Герасимов и Игнатов уже с латыни переводили на церковнославянский. Переписывали переведённые тексты, помимо троицкого монаха Селивана (названного в Послании иноком Силваном), которого Максим Грек обучал греческому языку и каллиграфии, лучшие московские каллиграфы Михаил Медоварцев (в Послании - Михаль Медоварцов) и Исаак Собака, писцы митропольичьей кафедры (см. об этом [10, с. 286-317; 5, с. 248-266; 12, с. 62-64]). Таким образом, Толковая Псалтырь - итог коллективного труда, где вырабатывались принципы переводческой деятельности, основанные на соблюдении норм церковнославянского языка, ориентированного по преимуществу на систему старославянского языка с вкраплением древнерусских элементов, которым Максим Грек следовал до конца своей жизни. Уже в первой четверти XVI в. начали закладываться основы формирования высокого стиля русского литературного языка, и Максим Грек сыграл в этом процессе огромную роль. Несколько позднее народный язык русичей «вовлёк старославянский язык в свою орбиту, пронизал его лексический состав и грамматический строй живыми народными элементами и, в конечном счёте, воспользовался им как частью материала по выработке своего собственного литературного языка определённой эпохи» [3, с. 39]. Пока же в Толковой Псалтыри явное преимущество отдаётся церковнославянским языковым средствам, хотя исследователи рукописей произведений Максима Грека со следами его собственных правок, отмечают тенденцию к обрусению, далеко не однозначно воспринимавшуюся даже его сотрудниками. Следы русификации легко обнаружить и в переводной Псалтыри (ср., напр., Иван Златоуст вместо Иоанн Златоуст, яко вместо aкbl, рожения вместо рождения, услажая вместо услаждая и пр.).

Закончив работу над Толковой Псалтырью «по к $\mathbf{6 T \mathbf { 6 }}$ єднномь и пати мъсАцєХъ〉, Максим Грек надеялся вместе со своими спутниками вернуться в Ватопед. В Послании к Василию III он пишет: «Мне же и сущим со мною братьям даровати да изволиши возвращение ко Святой Горе, к честному монастырю Ватопеди, издавна нас, подобно птенцов, ожидающей и чающей всечасно (встречи - С. Ш.), да не лишимся многолетних тамошних трудов и потов наших, которые мы положили там» [Послание 1522: л.•ѐ• об.].

Но Василий III не отпустил Максима Грека из Москвы. И не только потому, что слишком уж многое этот чужеземец узнал о России. Всё же русский царь был достаточно умён, чтобы понимать, как полезен для его ( С. Г. Шулежкова, 2015. 
страны этот талантливый человек. И 38 лет (27 из которых он провёл в заточении) до своей кончины (1556 г.) прожил Максим Грек в Московии, где написал более 300 самых разнообразных сочинений, как переводных, так и оригинальных.

А как же сложилась судьба переводческого шедевра Максима Грека? Разные фрагменты Толковой Псалтыри имели широкое хождение в многочисленных рукописных списках разных веков [7, с. 100-101; 12, c. 61-73; 6, с. 360-371]. Но наиболее полным и самым качественным следует признать список, выполненный в 1592 г. по велению Ионы Думина [ГИМ, Собр. Хлудова, №4А], «который вошёл в отечественную историю не только как талантливый книжник, но и как опытный церковный администратор <..> а также как собиратель редких книг, написанных другими книжниками» [17, http].

И всё же, если судить по доступным нам источникам, несмотря на огромную популярность Максима Грека и его творчества, до самого конца XIX в. его Толковая Псалтырь так ни разу не была издана, хотя ещё при жизни знаменитого учёного в Москве начала действовать анонимная типография, с 1551 по 1562 гг. опубликовавшая 7 богослужебных книг, а в 1563 г. при Иване Грозном открылся государственный Печатный Двор, снабдивший русские церкви «Апостолом» (1564 г.), «Часовником» (1563 г.) и даже «Псалтырью» (1568 г.).

Причин такого «небрежения» несколько. И одна из них конкуренция толковых псалтырей с Псалтырью служебного типа. Как справедливо пишет А. Вознесенский, «История печатной Псалтыри - это главным образом история служебного её типа» [4, с. 215]. Именно в служебной Псалтыри прежде всего нуждалась Православная церковь на Руси, а потому среди переводов, сделанных Максимом Греком (а их насчитывается более 100 [12, с. 58]), есть не только Толковая Псалтырь, но и переводы псалмов без толкования. Кроме того, в 1540 г. Максим Грек переписал по заказу тверского ризничего Вениамина греческую псалтырь, сопроводив её множеством славянских и русских материалов [12, с. 155], а в 1552 г. вместе с Нилом Курлятевым осуществил перевод Псалтыри, известный по пяти спискам краткой и пространной редакции [2, http].

Вторая причина, по которой Толковая псалтырь, несмотря на блестяще сделанный перевод и огромную познавательную ценность, оказалась на периферии исследовательских интересов отечественных и зарубежных славистов, - опала, которой подвергся Максим Грек. Спустя три года после завершения работы над Толковой псалтырью посланец из Ватопеда не одобрил решения великого князя Василия III расторгнуть 
брак с бесплодной супругой Соломонией. Позднее, будучи затворником, Максим Грек в «Главах поучительных к начальствующим правоверных» писал, что по Божественному закону государь не должен покоряться плотским страстям, что самодержец - тот, кто умеет самого себя держать в руках, охраняя себя от трёх греховных страстей - «сластолюбия, славолюбия и сребролюбия» $[16, \mathrm{http}]$. Гнев великого князя дал повод завистникам и противникам Максима Грека обвинить его в измене и ереси. Ссылаясь на погрешности, допущенные М. Греком при переводах Толковой псалтыри и Апостола, Церковный собор 1525 г. определил: «Максимка множайшаго демонскаго нечестия и ереси исполнен есть», и, закованный в кандалы, писатель был отправлен к месту заточения. Этот вердикт был повторён на соборе 1531 г., что не могло не отразиться на отношении и светской, и церковной власти как к оригинальным, так и к переводным трудам опального инока. Тем более что опасаться острого слова Максима Грека, присоединившегося к партии «нестяжателей», были основания. Насмотревшись на русские порядки, он писал: «Нет ни одного на Руси, кто бы прилежно поучал и вразумлял бесчинных, утешал малодушных, заступался за бессильных, обличал противящихся слову благочестия, запрещал бесстыдным, обращал уклонявшихся от истины и честного образа христианской жизни» $[9, \mathrm{http}]$.

Третья причина малой изученности Толковой Псалтыри кроется в том, что в XVII в. противники реформ Никона нашли опору своим взглядам не только в староотеческих источниках, но и в богословских сочинениях Максима Грека. Это, естественно, не способствовало пропаганде, тем более публикации произведений афонского старца вплоть до конца XIX в. Но даже когда в легальной печати появились собрания сочинений Максима Грека (см., напр., три книги, выпущенные Казанской духовной академией [13], и трёхтомник с сочинениями, переведёнными с церковнославянского на русский язык в Троице-Сергиевской Лавре [14]), Толковая Псалтырь не была в них включена. Нет Толковой Псалтыри и в изданиях начала XXI в. Возможно, не только объём работы сдерживает издателей. Обвинения в ереси на соборах 1525 и 1531 гг,, а также огромный авторитет, которым продолжает пользоваться Максим Грек среди старообрядцев, тоже сыграли свою роль в судьбе Толковой Псалтыри.

Лишь в 1897 г. Толковая Псалтырь была издана «единоверцами» по списку Ионы Думина [1, с. 110], но уже давно каждая книга этого тиража стала библиографической редкостью. Осознавая диспропорцию между степенью изученности памятников, касающихся судного дела Максима Грека и его филологического наследия, современные лингвисты должны (с) С. Г. Шулежкова, 2015. 
воздать должное великим творениям Максима Грека, с которых началась его новаторская переводческая деятельность, оказавшая огромное влияние на развитие русского литературного языка. Богатейший язык Толковой Псалтыри, в котором скрестились две тенденции - стремление к правильности церковнославянского слога и разумной его русификации, может стать основой для пополнения научных знаний о состоянии особой разновидности литературного языка первой половины XVI столетия, а также базой для создания церковнославянского словаря этой эпохи.

\section{Литература}

1. Буланин Д. М. Иона Думин / Д. М. Буланин // Труды Отдела древнерусской литературы. - Т. 40 - Л. : Наука, 1985. - С. 109-110.

2. Буланин Д. М. Нил Курлятев [Электронный ресурс] / Д. М. Буланин // Словарь книжников и книжности Древней Руси. Вып. 2 (вторая половина XIV -XVI в.). Ч. 2. Л-Я ; отв. ред. Д. С. Лихачев. - Л. : Наука, 1989. - Режим доступа : http://www.pushkinskijdom.ru

3. Виноградов В.В. Проблемы литературных языков и закономерностей их образования и развития / В. В. Виноградов. - М. : Наука, 1967. - 136 с.

4. Вознесенский А. В. Служебная Псалтирь в восточнославянском книгопечатании XVI - XVIII вв. / А. В. Вознесенский // Труды Отдела древнерусской литературы. Т. 50. - СПб. : Наука, 1996. - С. 215-216.

5. Казакова Н. А. Дмитрий Герасимов и русско-европейские культурные связи в первой трети XVI в. / Н. А. Казакова. // Проблемы истории международных отношений : сб. статей памяти академика Е. В. Тарле. - Л. : Наука, 1972. - С. 248-266.

6. Казимова Г. А. Церковнославянская Толковая Псалтирь второй половины XVIXVIII веков Г. А. Казимова // Лингвистическое источниковедение и история русского языка. - М. : Древлехранилище, 2003. - С. 360-371.

7. Ковтун Л.С. Максим Грек и славянская Псалтырь : (Сложение норм литературного языка в переводческой практике XVI в.) / Л. С. Ковтун, Н. В. Синицына, Б. Л. Фонкич // Восточнославянские языки : Источники для их изучения. - М. : Наука, 1973. - С. 99-127.

8. Петрушко В. Преподобный Максим Грек [Электронный ресурс] / В. Петрушко // Седмица - 23.12.2006. - Режим доступа : http://www.k-istine.ru

9. Святая Гора Афон: информационный портал [Электронный ресурс]. - Режим доступа : http://www.isihazm.ru/

10. Синицына Н. В. Книжный мастер Михаил Медоварцев / Н. В. Синицына // Древнерусское искусство. Рукописная книга. - М. : Наука, 1972. - С. 286-317.

11. Синицына Н. В. Максим Грек [Электронный ресурс] / Н. В. Синицына. - М. : Молодая гвардия, 2008. - 236[4] c. - Режим доступа : http:/lib.pravmir.ru/library

12. Синицына Н. В. Максим Грек в России / Н. В. Синицына ; под ред. акад. Л. В. Черепнина. - М. : Наука, 1977. - 332 с.

13. Сочинения преподобного Максима Грека : в 3-х ч. / М. Грек. - Казань : Казанская духовная академия, $1859-1862$.

14. Сочинения преподобного Максима Грека в русском переводе : в 3-х ч. / $-399-$

(с) С. Г. Шулежкова, 2015. 
М. Грек ; предисл., перевод : послушник Моисей. - Троице-Сергиева Лавра: Собственная типогр., 1910-1911.

15. Сперанский Н. М. Из истории русско-славянских литературных связей [Электронный ресурс] / Н. М. Сперанский. - М. : Госучпедиздат, 1960. - С. 192-197. - Режим доступа : http://omelike.eu.pn

16. Столярова В. Он не боялся обличать самого царя [Электронный ресурс] / В. Столярова. - Режим доступа : http://www.pravmir.ru

17. Торопов А. Митрополит Иона (Думин) как книжник и церковный администратор [Электронный ресурс] / А. Торопов. - Режим доступа : http://www.voskres.ru/podvizhniki

18. Шашков А. Т. Максим Грек и идеологическая борьба в России во второй половине XVII - XVIII в. (Подделка и её разоблачение) / А. Т. Шашков // Труды Отдела древнерусской литературы. - Л. : Наука, 1977. - С. 80-87.

\section{Источники}

Иона Думин. Послесловие // Святая Книга. Псалтырь Толковая. - М. : б. в., 1897. Л. $\cdot t^{\text {à̀àे} \bullet}$

Максим Грек. Послание Василию III // Святая Книга. Псалтырь Толковая. - М. : б. в., 1897. -Л •à॰ ••f

Максим Грек. Псалтырь Толковая. ГИМ, Собр Хлудова №4А.

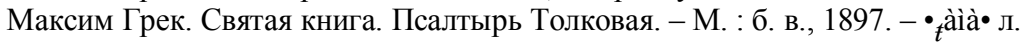

Стаття надійшла до редакиії 14.07.2015 p. 